\title{
PETA DUNIA ISLAM : SYI'AH, SUNNI DAN AHMADIYAH
}

\author{
Oleh: \\ Muliati \\ E-mail: sesady.muliati@gmail.com
}

\section{PENDAHULUAN \\ A. Latar Belakang Masalah}

Dari empat disiplin ilmu keislaman yang mapan, tasawuf, kalam, fiqih, dan filsafat atau al-hikmah yang terakhir ini paling kuat mendominasi pemahaman masyarakat muslim akan agama mereka. Kenyataan tersebut dapat dikembalikan pada benih munculnya persoalan kalam di tengah-tengah masyarakat muslim sejak meninggalnya Nabi saw., dan semakin tumbuh menjelang berakhirnya dekade ketiga Khulafa Al-Rasyidin, yaitu di akhir pemerintahan khalifah Usman bin Affan dan diawal pemerintahan Ali bin Abu Thalib Sebab utama goyahnya kesatuan umat Islam tersebut berpangkal pada pertikaian politik yang bercorak kalam kemudian melahir-kan sekte-sekte di antara kelompok-kelompok muslim yang sedang bersaing. ${ }^{1}$ Peristiwa tersebut merupakan awal masa desintegrasi yang dalam perkembangan kalam selanjutnya, terutama sesudah terbunuhnya khalifah ketiga, Usman, benar-benar mendorong lahirnya sekte-sekte dalam Islam dengan doktrin ajaran yang masing-masing berbeda antara satu dengan lainnya.

Sekte besar yang pertamakali muncul dalam peta dunia Islam adalah Syi'ah, sebagai kelompok muslim yang mendukung Ali, dan menjadikan Ali sebagai imam setelah Nabi saw., Syi'ah sangat percaya bahwa Nabi saw

\footnotetext{
${ }^{1}$ Mereka bersaing dalam perebutan kekuasaan di mana ketika Ali menjadi khalifah menggantikan 'Uśmān yang telah wafat, ia mendapat tantangan dari pemuka-pemuka yang ingin pula menjadi khalifah. Tantangan pertama, datang dari Zubayr dan Thalhah di Mekah yang memperoleh dukungan dari Aisyah isteri Nabi saw., Tantangan dari tiga pemuka ini dapat dipatahkan oleh Ali dalam pertempuran di Rak pada tahun $656 \mathrm{H}$. Thalhah dan Zubayr mati terbunuh sedang Aisyah diantar kembali ke Mekkah. Tantangan lain yang lebih dahysat lagi datang dari pihak Muawiyah, gubernur Damaskus, yang mendapat dukungan dari keluarga 'Uśmān. Mereka menuntut Ali menjatuhkan hukuman atas pelaku pembunuhan 'Uśmān. Oleh karena Ali tidak mengambil tindakan, maka Ali pun dituduh turut campur dalam pembunuhan 'Uśmān. Dari sini terjadilah pertempuran, dan ujung dari pertempuran ini diusulkan adanya tahkīm (arbitrase), namun sebagian pengikut Ali tidak menginginkan diadakan tahkim, dan mereka menganggap bahwa Ali telah menyimpang hukum Allah. Mereka yang tergolong dalam bagian ini, akhirnya keluar dari pengikut setia Ali yang kemudian disebut aliran khawarij. Sementara sebagian mereka yang tetap setiap pada Ali kemudian disebut aliran Syi'ah. Dalam sejarah yang cukup panjang, lahir pula aliran-aliran lain sebagai perkembangan dari dua aliran sebelumnya. Beberapa aliran yang muncul sesudahnya, seperti Murji'ah, Mu'tazilah, Asy'ariyah, dan yang terakhir ini paham teologinya lebih dikenal dengan sebutan Ahlussunnah dan disimbolkan dengan Sunni. Ann K.S. Lambton, State and Govermen in Medival Islam. (Oxford: University Press, 1981), h. 36-38. Lihat Badri Yatim. Sejarah Peradaban Islam Dirasah Islamiyah II. (Cet. XXI; Jakarta: Rajawali Pers. 2008). h. 67-68.
} 
sebelum meninggalnya telah menentukan penggantinya, yaitu Ali, saudara sepupunya sendiri, dan sekaligus menjadi menantunya, suami dari Fāthimah alZahrah, anak perempuan Nabi saw., Syi'ah tidak seperti kaum muslimin lainnya, hanya mau berpegang pada apa yang mereka terima dari Ali dan Ahlul Bait, keluarga Nabi saw., serta keturunannya dalam segala hal yang bersangkutan dengan pemahaman keagamaan.

Berlawanan dengan itu, ada juga sekte besar dalam Islam yang menolak anggapan bahwa Nabi saw., telah menunjuk Ali menggantikannya sebagai pemimpin komunitas Islam, dan sekte inilah dikenal dengan nama Sunni, atau pengikut sunnah yang disepadangkan dengan Ahlul al-Sunnah. Sunni berpendapat bahwa Nabi saw., adalah rasul Allah yang terakhir, dan nabi atau rasul ini tidak pernah menentukan siapa yang akan menggantikan kedudukannya dalam memerintah kaum muslim sepeninggalnya. Dengan demikian menurut Sunnī, umat Islam telah diberi kekuasaan untuk menunjuk salah seorang dari kalangan umat itu yang akan menjadi pemimpin atau penguasa dari kaum muslim.

Pada perkembangan selanjutnya, terutama menjelang penghujung abad ke-19, muncul lagi sekte baru dalam peta dunia Islam yang disebut Ahmadiyah. Sekte ini berpaham bahwa Muhammad saw., bukan Nabi terakhir sebagaimana yang dipahami Sunnī. Ahmadiyah juga berpaham bahwa silsilah kepemimpinan dalam Islam tidak sebatas pada keturunan Nabi saw., atau ahl al-bayt sebagaimana yang dipahami Syi'ah, tetapi siapa saja yang dikehendaki Allah baik dengan jalan wahyu atau ilham.

Pemaparan di atas memperlihatkan bahwa dalam peta dunia Islam, ada tiga sekte-aliran yang pemahamnnya saling berbeda, dan doktrin mereka pada hal-hal tertentu saling kontroversial. Kehadiran ketiga sekte tersebut sangat menarik untuk dikaji, terutama dalam hal sejarah kemunculannya, doktrin keagamannya dan per-kembangannya dalam peta dunia Islam sampai era sekarang.

\section{B. Rumusan Masalah}

Berdasar pada uraian latar belakang sebelummnya, maka permasalahan yang menjadi pokok pembahasan dalam kajian ini, adalah bagaimana eksistensi Syī'ah, Sunn̄̄, dan Ahmadiyah dalam peta dunia Islam.

Untuk kajian lebih lanjut, berikut ini dikemukakan beberapa sub masalah, dan sekaligus sebagai batasan pembahasan, yakni :

1. Bagaimana sejarah singkar kemunculan Syi'ah, Sunni dan Ahmadiyah dalam peta dunia Islam ?

2. Bagaimana doktrin paham keagamaan Syi'ah, Sunni dan Ahmadiyah ?

3. Bagaimana perkembangan Syi'ah. Sunni dan Ahmadiyah dalam peta dunia Islam dewasa ini ?

\section{PEMBAHASAN}

\section{A. Sejarah Singkat Kemunculan Syi'ah, Sunni dan Ahmadiyah}

Syi'ah adalah salah satu aliran dalam Islam yang berkeyakinan bahwa yang paling berhak menjadi imam ummat Islam sepeninggal Nabi Muhammad saw., ialah keluarga Nabi saw., sendiri (ahlulbait). Dalam hal ini, Abbas bin 
Abdul Muttalib (paman Nabi saw) dan Ali bin Abi Thalib (saudara sepupu dan sekaligus menantu Nabi saw) beserta keturunannya. ${ }^{2}$

Gambaran singkat dan jelas tentang lahirnya mazhab Syi'ah atau yang dikenal mazhab Ahlul Bait tidak akan terlepas dari kehidupan Nabi saw., dan Ali. Nabi saw., sebagai shahib al-Syari'ah telah memberikan tuntunan dan garis tasyayyu' (ke-syi'ah-an) kepada Ali, dan Ali sebagai pengemban amanah tasyayyu' punya hubungan khusus yang eksklusif dengan Nabi saw. ${ }^{3}$

Penganut aliran Syi'ah dan juga sekian pakar dari Ahlussunnah berpendapat bahwa benih Syi'ah muncul sejak masa Nabi Muhammad saw., atau paling tidak secara politis benihnya muncul saat wafatnya Nabi Muhammad saw., (pembaiatan Sayyidina Abubakar di Tsaqifah). Ketika itu keluarga Nabi saw., dan sejumlah sahabat memandang bahwa Sayyidina Ali bin Abi Thalib ra. lebih wajar dan lebih berhak menjadi khalifah Nabi saw., ketimbang Sayyidina Abubakar ra. Pendapat tentang benih lahirnya Syi'ah seperti ini, antara lain dikemukakan oleh Ibnu Kaldun dalam Tarikh-nya ${ }^{4}$.

Pendapat di atas yang intinya adalah bahwa hubungan yang demikian erat antara Nabi Muhammad saw., dengan Sayyidina Ali ra. telah terjalin sebalum Islam, yakni ketika Nabi saw., mengambil Sayyidina Ali untuk dipelihara demi meringankan beban paman beliau, Abu Thalib, yang juga adalah ayah Sayyidina Ali ra.

Versi lain menyatakan bahwa salah satu kelebihan Ali ialah, ia dilahirkan di Ka'bah, yang merupakan kiblat kaum Muslim, dan waktu kelahirannya terjadi ketika seruan Islam hampir disampaikan oleh Muhammad. ${ }^{5}$ Dari sejak Ali masih belia. Nabi sudah dekat sekali dengannya dan berkata bahwa Ali adalah saudaranya. Di saat dakwah Islam diserukan, Khadījah dan Ali termasuk barisan pertama yang menyambut seruan itu. Dari kecil Ali tidak pernah bersujud kepada berhala, ia adalah "karramallahu wajhahu”.

Kelebihan Ali bin Abutalib yaitu: Ali son of abutalib - anecdotes are on record illustrating the asceticism and piety of the fourth caliph. He was a fervent moslem, free both in speech and in action, unacquainted with crooked ways, and unable to employ ruses, his sole concern was religion, and the basis ao all his actions was the truth. Asan illustration of his

${ }^{2}$ Taufik, Abdullah. Ensiklopedi Tematis Dunia Islam. ( Jilid 3. Jakarta: PT Ichtiar Baru Van Hoeve, 2002) h. 343.

${ }^{3}$ Di masa kecil Nabi saw., sepeninggal Abd. al-Muththalib, ayah Ali-lah yang mengasuh Nabi saw., Abu Talib mencintai kemanakannya itu sama seperti Abdul Muththalib. Karena kecintaannya pula, ia mendahulukan kemenakannya dari pada anakanaknya sendiri. Budi pekerti Muhammad yang luhur, cerdas, suka berbakti dan baik hati, itulah yang menarik hati pamannya. Kemudian abu Talib mengajarkan-Nya berdagang. Lihat Muhammad, Husain Haekal. Sejarah Hidup Muhammad. (Cet.36.Jakarta: PT. Pustaka Litera AntarNusa, 2008). h. 58.

${ }^{4}$ Quraish, Shihab, Sunnah-Syiah Bergandengan Tangan! Mungkinkah? Kajian Atas Konsep Ajaran dan Pemikiran. (Cet. I; Jakarta: Lentera Hati, 2007) h. 66.

${ }^{5}$ George, Jordac. Suara Keadilan Sosok Agung Ali bin Abi Thalib R.A. (Cet. II; Jakarta: Lentera, 2000). h. 30. 
plainness of living, it is recorded that when he married fatimah, the prophet's daughter, they had no bedsave a ram's skin to lie on at night, and to feed their camel from in the daytime. ${ }^{6}$

Artinya:

Ali bin abutalib - anekdot yang pada catatan yang menggambarkan asketisme dan kesalehan khalifah keempat. Dia adalah seorang muslim kuat, bebas baik dalam pidato dan tindakan, yang tidak akrab dengan cara miring, dan tidak mampu mempekerjakan tipu muslihat, kekhawatiran utamanya adalah agama, dan ao dasar semua tindakannya adalah kebenaran. Asan ilustrasi kepolosan hidupnya, tercatat bahwa ketika ia menikah Fatimah, putri nabi, mereka tidak bedsave kulit domba jantan untuk berbaring di malam hari, dan untuk memberi makan unta mereka dari pada siang hari.

Ali bin Abi Thalib bin Abdul Mutthalib. Sepupu Rasulullah. Rasulullah mengawinkan putrinya Fatimah dengannya. Ali adalah salah satu dari sepuluh orang sahabat yang mendapat jaminan langsung masuk surga dari Rasulullah. ${ }^{7}$

Dalam satu perjamuan yang diadakan oleh Nabi saw., dengan dihadiri empat puluh kerabat dekat Nabi saw., termasuk para paman Nabi saw., Abū Thālib, Hamzah, Abū Jahal, Abū Lahab dan Abbās, ditawarkan kepada yang hadir, bahwa siapa saja yang memberikan dukungan dalam mengemban tugas ke Nabi saw., itu ia akan diangkat menjadi khalīfah, washy (pemegang wasiat) dan saudara Nabi saw., Namun semua yang hadir diam, kecuali Ali. Ia memberikan kesanggupannya untuk selalu membantu Nabi saw., dalam setiap tugas kenabiannya. Karena ia menjadi wali, khalifah dan washy Rasulullah saw. Setelah dakwah Islam berjalan dengan penuh tantangan, intrik-intrik jahat, intimidasi, siksaan fisik, yang semuanya ditujukan untuk membendung gerakan dakwah Islam, maka Nabi saw., mengambil keputusan untuk berhijrah ke Madinah. Dalam proses keberangkatan inilah Ali mempertaruhkan nyawanya untuk keselamatan Nabi saw.

Di awal hijrah Nabi saw., ke Madinah, strategi dakwah ditetapkan oleh Nabi saw dengan mempersaudarakan antar setiap muslim. Hamzah dipersaudarakan dengan bekas budaknya, Zaid. Abdurrahman bin 'Auf dipersaudarakan dengan orang Anshar, Sa'ad bin Rabi'. Abu Bakar dipersaudarakan dengan Umar. Sedang Nabi saw mengangkat Ali sebagai saudaranya. Peristiwa ini terjadi pada bulan kelima setelah hijrah. Peristiwa ini dicatat oleh Thabarāny dan Hākim dalam Mustadraknya bahwa: $\left(.^{8}\right.$

Kenyataan bahwa Nabi saw., mengangkat "Ali sebagai saudaranya di dunia dan di akhirat" sebenarnya tidak jauh berbeda dengan tindakan Musa dalam meminta kepada Allah agar Harun dijadikan wazirnya, pembantunya

${ }^{6}$ D.S. Margoliouth, D.Litt. Umayyah and 'Abbasids Being The Fourth Part of Jurji Zaydan's of Islamic Civilization. (London: Kitab Bhavan New Delhi, 1978). h. 39

${ }^{7}$ Ahmad, Al-Usairy. Sejarah Islam Sejak Zaman Nabi Adam Hingga Abad XX. Di terjemahkan oleh Ali Audah. (Cet. VIII; Jakarta: Akbar Media,2010). h. 172.

${ }^{8}$ Al-Iman al-Hafid Jalaluddin Abd Al-Rahman bin Abu Bakar al-Suyuthy. Tarikh alKhulafa. (Cet. I; Mesir: Matbaah as-Saadah, 1952). h. 170. 
dalam urusan dakwah dan kenabian, sehingga memperkokoh kedudukan Musa dalam menyampaikan tugas risalah.

Muhammad Jawad Mughniyah, seorang penulis kelahiran Libanon, menolak pendapat penulis-penulis Barat, yang mengatakan bahwa sebab munculnya Syì'ah adalah usaha politis untuk mendudukkan Ali sebagai khalifah sepeninggal Nabi saw., Pendapat demikian - menurut Jawad Mughniyah - tidak benar. Ia menegaskan bahwa Syi'ah lahir karena nash-nash yang langsung datang dari shahib al-Syari'ah. Jadi, ia lahir bukan karena hasrat dan perjuangan politis. Nash ini menurut Jawad ada yang berupa perbuatan dan ada pula yang berupa perkataan. ${ }^{9}$

Jawad melanjutkan, perbuatan Nabi saw., yang mengindikasikan demikian adalah pemilihan atas Ali sebagai saudaranya, sekali di Mekkah dan sekali di Madinah. Nabi saw., mendidik dan mengajar Ali sejak masih sangat muda belia. Nabi saw., pernah mengangkat Ali sebagai pembantunya dalam mengajarkan agama Islam di kalangan keluarganya. Ali sejak kecil selalu mendampingi Nabi saw., dalam urusan-urusan penting sampai Nabi saw., wafat, dari sejak urusan da'wah, rumah tangga, sampai urusan perang. Ali diangkat menjadi menantunya, menjadi suami Fathimah, puteri yang sangat disayanginya. Nabi saw., mencintai kedua anak Ali, Hasan dan Husein. Nabi saw., menamakan keduanya sebagai wewangiannya. Masih pendapat Jawad Mughniyah bahwa, lahirnya Syi'ah bersamaan dengan lahirnya nash-nash itu sendiri. Pendukung-pendukung Syi'ah generasi sahabat antara lain adalah: Salman al-Farisi, Abdullah ibn Abbās, Miqdad bin Aswad, Abū Dzar alGhiffary, Jabir bin Abdullah, Sahl bin Hunsif, Abū al-Haitsam bin Tyhan, dan semua Bani Hasyim.

Muhammad al-Jurjani (1339-1413 M) seorang Sunni penganut aliran Asy'ariyah, berpendapat bahwa: yang menulis dalam bukunya At-Ta'rifat Syi'ah adalah mereka mengikuti Sayyidina Ali ra. dan percaya bahwa beliau adalah Iman sesudah Rasul saw., dan percaya bahwa imamah tidak keluar dari beliau dan keturunannya. ${ }^{10}$ Definisi ini kendati hanya mencerminkan sebagian dari golongan Syi'ah bukan seluruhnya namun untuk sementara dapat diterima karena kandungannya telah menunjuk kepada Syi'ah yang terbanyak dewasa ini, yakni Syi'ah Isna 'Asyariyah.

Akhir masa sahabat bersamaan ketika Ali baru mendapat kesempatan sebagai khalifah, terjadi tahkim (arbitrase) yang tampaknya dalam kejadian tersebut Ali menjadi terpojokkan, dan umat Islam terpecah dalam beberapa sekte-mazhab. ${ }^{11}$ Dalam situasi yang demikian, sebagian di antara mereka tetap

${ }^{9}$ Abu Bakar Aceh, Syi'ah Rationalisme dalam Islam (Solo: Ramadlani, 1984), h. 13.

${ }^{10}$ Quraish Shihab, op.cit. h. 61.

${ }^{11}$ Mengenai kemunculan Syi'ah dalam sejarah, terdapat perbedaan pendapat di kalangan para ahli. Menurut Abu Zahra, Syi'ah mulai muncul pada akhir pemerintahan Usman bin Affan kemudian tumbuh dan berkembang pada masa pemerintahan Ali bin Abi Thalib. Adapun menurut Watt, Syi'ah benar-benar muncul ketika berlangsung peperangan antara Ali dan Mu'awiyah yang dikenal dengan perang Siffin. Dalam peperangan ini, sebagai respon atas pemerintahan Ali terhadap Arbitrase yang ditawarkan 
setia pada Ali dan kemudian mereka inilah yang dikenal pengikut mazhab Syi'ah, pengikut setia Ali. Pengikut mazhab semakin eksis terutama ketika mereka mengangkat Hasan ibn Ali ibn Abu Thalib sebagai imam kaum Syi'ah, dan berlanjut sampai pada imam dua belas, yakni Husen bin Ali ibn Abu Thalib, Ali Zainal Abidin bin Husein, Muhammad al-Baqir bin Ali, Ja'far alShadiq, Musa bin Ja'far, Ali al-Ridha bin Musa, al-Jawad bin Ali, Ali al-Hadi, Hasan al-Askary, al-Ghaibaih al-Hujjah al-Mahdi.

Dari uraian di atas dapat diketahui bahwa Syi'ah muncul saat wafatnya Nabi Muhammad saw., (pembaiatan Sayyidina Abubakar di Tsaqifah), ketika itu keluarga Nabi saw., dan sejumlah sahabat memandang bahwa Sayyidina Ali bin Abi Thalib ra. lebih wajar dan berhak jadi khalifah ketimbang Sayyidina Abubakar. Hal ini diperkuat karena Ali bin Abi Thalib sepupu Rasulullah, Rasulullah mengawinkan putrinya Fatimah dengannya. Kemudian Nabi Muhammad menyatakan "Adapun engkau hai Ali adalah saudaraku di dunia dan di akhirat" pernyataan ini memeperkuat posisi Syi'ah bahwa yang berhak menjadi khalifah sesudah wafatnya Rasulullah saw., adalah Ali bin Abi Thalib.

Bila kembali ditelusuri sejarahnya, maka kelahiran mazhab dalam Islam dapat diklasifikasi atas dua aliran. Pertama, mazhab yang beraliran politik, dan yang kedua, mazhab yang beraliran teologi. Mazhab yang latar belakang berdirinya dimotivasi dengan masalah khilafah atau imamah, dikelompokkan sebagai mazhab yang beraliran politik, seperti Syi'ah dan Khawarij. Sedangkan mazhab yang latar belakang berdirinya dimotivasi dengan masalah kepercayaan, dikelompokkan sebagai mazhab yang beraliran teologi, seperti Muktazilah, Asy'ariyah, Maturidiyah. Dua mazhab yang disebut terakhir ini, selanjutnya dikenal dengan mazhab Sunnī.

Mazhab Sunnī lazimnya dikenal mazhab Ahlus Sunnah, dan sejarah kelahiranya sebagaimana Syi'ah berproses dalam sejarah yang panjang, di mana jauh sebelum ia muncul, telah ada mazhab-mazhab atau aliran teologi dalam Islam yang bermula sejak timbulnya pembicaraan tentang pelaku dosa besar di akhir kekuasaan khalifah Ali bin Abu Thalib. Teologi Mu'tazilah bersifat rasional dan liberal itu begitu menarik bagi kaum intelengensia yang terdapat dalam lingkungan pemerintahan Kerajaan Islam Abbasiyah dipermulaan abak ke- 9 M. Sehingga khalifah Al-Ma'mun (813-833 M), pera dari khalifah Harun Al-Rasyid (766-809 M) di tahun 827 M menjadikan teologi Mu'tazilah sebagai mazhab yang resmi dianut negara. Karena telah menjadi aliran resmi dari pemerintah, kaum Mu'tazilah mulai bersikap menyiarkan ajaran-ajaran mereka secara pakasa, terutama paham mereka bahwa Al-Qur'an bersifat mahkluq dalam arti kekal dan tidak diciptakan. ${ }^{12}$

Muawiyah, pasukan Ali terpecah menjadi menjadi dua. Kelompok mendukung Ali kelak disebut Syi'ah dan kelompok yang menolak Ali disebut disebut Khawarij. Abdul Rozak, Rosihon Anwar, Ilmu Kalam. (Cet. II; Bandung: CV. Pustaka Setia. 2006). h. 90.

${ }^{12}$ Harun Nasution, Teologi Islam Aliran-Aliran Sejarah Analisa Perbandingan, (Cet. V; Jakarta: Universitas Indonesia, 1986). h. 8. 
Sejak itu mazhab Mu'tazilah merosot, dan menjadi lemah karena menghadapi tantangan-tantangan dari berbagai golongan, dan yang paling keras adalah tantangan dari golongan Hambali. Pengikut paham Hambali, akhirnya mengambil bentuk mazhab teologi baru yang bertumpu pada sunnah (tradisi) yang kemudian dikenal sebagai aliran tradisional dengan sebutan mazhab teologi Asy'ariyah yang dalam perkembangan selanjutnya dikenal dengan Ahlus Sunnah. Mazhab ini yang bersumber dari teologi Asy'ariy, telah banyak dianut ummat Islam, maka selanjutnya tampillah Muhammad bin Abd Wahab yang ingin membersihkan faham-faham khurafat dan bid'ah di tengah masyarakat, dengan memperjuangkan pendapat kaum salaf. Hal ini dapat dilihat dari komunitas mayoritas muslim sekarang ini adalah berfaham Sunni, walaupun secara formal tidaklah demikian, akan tetapi secara emosional akan tampak jelas dari cara berpikir dan bertingkah.

Sunnah secara harfiah berarti tradisi, Ahlussunnah berarti orang-orang yang secara konsisten mengikuti tradisi Nabi Muhammad saw., dalam hal ini adalah tradisi Nabi dalam tuntunan lisan maupun amalan beliau serta sahabat mulia beliau. ${ }^{13}$

Versi lain menyatakan bahwa kelompok Ahlus Sunnah muncul sebagai sebagai reaksi atas paham Mu'tazilah, yang disebarkan pertama kali oleh Washil bin 'Atha' (w. $131 \mathrm{H} / 748 \mathrm{M}$ ), yang sangat mengandalkan akal dalam memahami dan menjelaskan ajaran-ajaran Islam. Di samping aliran Mu'tazilah, ada lagi aliran Maturudiyah yang terbagi dalam dua kelompok besar, yang satu berpusat di Samarkand dengan pemahaman yang sedikit liberal dan yang satunya lagi muncul di Bukhara yang cendrung bersifat tradisional dan lebih dekat kepada aliran Asy'ariyah. Nah, kadua alitaran teologi yang disebut terakhir ini, Maturidiyah dan Asy'ariyah dimasukkan juga dalam kelompok Ahlus Sunnah. ${ }^{14}$

Mazhab Sunni lazimnya dikenal mazhab Ahlussunnah, mazhab ini bersumber dari teologi Asy'ariyah, telah banyak dianut ummat Islam, maka selanjutnya tampillah Muhammad bin Abd Wahab yang ingin membersihkan faham-faham khurafat dan bid'ah di tengah masyarakat, dengan memperjuangkan pendapat kaum salaf. Ahlussunnah berarti orang-orang yang secara konsisten mengikuti tradisi Nabi Muhammad saw ., dalam hal ini adalah tradisi Nabi dalam tuntunan lisan maupun amalan beliau serta sahabat mulia beliau.

Dalam kebesaran Ahlus Sunnah terbagi lagi menjadi dua aliran, yakni Imam Abu Mansur Muhammad bin Muhammad al-Maturidi al-Anshari. Dia hidup di Samarkand 238-333 H/852-944 M, dan yang kedua Imam Abul Hasan Ali bin Ismail al-Asy'ari.lahir di kota Basyrah 269-330 H/873-945M Dia H). ${ }^{15}$ Mazhab ini terus mengalami perkembangan sebagaimana mazhab Syī'ah,

\footnotetext{
${ }^{13}$ Quraish Shihab, op,cit., h. 57.

${ }^{14}$ Quraish Shihab, Ibid., . h. 58.

${ }^{15}$ Sahilun A. Nasir, Pemikiran Kalam (Teologi Islam) Sejarah, Ajaran, dan Perkembangan. (Cet. I; Jakarta: Rajawali Pers, 2010), h. 197-198.
} 
sehingga lahirlah Ahmadiyah adalah sebuah gerakan Islam yang didirikan oleh Mirza Ghulam Ahmad (1251-1326H/1839H/1835M-1908M). Seorang yang berasal dari Punyab, Ia menentang kegiatan misionari Kristen dan pada tahun 1882 ia menyatakan diri sebagai mujaddid (pembaharu). ${ }^{16}$

Versi lain menjelaskan gerakan Ahmadiyah merupakan ajaran Mizra Ghulan Ahmad. Dia dilahirkan di Qadian, distrik Gusdaspur, Punyab wilayah India, pada 1939 dan meninggal pada 1908. Menurut suatu riwayat, leluhurnya berasal dari Mongolia. Pada 4 Maret 1889 Ghulam Ahmad mengaku dan mengumukan bahwa dirinya menerima wahyu langsung dari Tuhan, menunjukkan sebagai Al-Mahdi Al-Mau'ud, Artinya Imam Mahdi yang dijanjikan, agar masyarakat berbaiat (sumpah setia) kepadanya. ${ }^{17}$

Demikianlah gambaran umum yang melatar belakangi kelahiran Ahmadiyah yang dipelopori Mirza Ghulam Ahmad setelah ia melihat gencarnya serangan kaum missionaris Kristen dan propaganda kaum Hindu terhadap umat Islam saat itu. Mirza Ghulam Ahmad mengaku telah diangkat sebagai al-Mahdi dan Masih oleh Tuhan, merasa mempunyai tanggungjawab moral untuk memajukan Islam dengan memberi interpretasi baru terhadap ayat-ayat Alqur'an sesuai tuntutan zamannya.

Berdasar dari uraian siangkat tentang kelahiran Ahmadiyah di atas, dipahami bahwa Ahmadiyah lahir menjelang abad ke-19, di tengah huru-hara runtuhnya masyarakat Islam lama dan infilltrasi budaya, serta adanya serangan kaum misionaris Kristen terhadap Islam, maka lahirlah Ahmadiyah sebagai protes atas keberhasilan kaum missionaris yang banyak mendapat pengikut baru. bahwa,

Mengenai eksistensi Ahamadiyah, dijelaskan oleh John L. Esposito

Ahmadiyah, a messianic movement in modern Islam, the hmadiyah has been one of the most actiove and controvesial movements since its inception in Britis India in 1889. It has sustained its activities for more than century and has been unrivaled in its dedication to the propogation of the faith. ${ }^{18}$

Artinya :

Ahmadiyah adalah gerakan mesianik dalam Islam modern. Gerakan ini merupakan salah satu gerakan paling aktif dan paling kontroversial sejak kelahirannya di India Inggris tahun 1889. Ia berhasil mempertahankan kegiatannya selama lebih dari seabad dan tidak tersaingi dedikasinya dalam menyebarkan keyakinan.

${ }^{16}$ Cyril Glasse, The Concise Encyclopedia of Islam diterjemahkan oleh Ghufran Mas'adi dengan judul Ensiklopedi Islam; Ringkas (Cet. III; Jakarta: RajaGrafindo Persada, 2002), h. 16.

${ }^{17}$ Sahilun A. Nasir. Pemikiran Kalam (Teologi Islam) Sejarah, Ajaran dan Perkembangannya, op.cit., h. 326.

${ }^{18}$ John L. Esposito. The Oxford Encyclopedia Of The Modern Islamic World. (New York: Oxfoord Universitt 1995). h. 54. 


\section{B. Doktrin Paham Keagamaan Syi'ah, Sunnī, dan Ahmadiyah}

Dari ketiga aliran-mazhab yang dikaji, masing-masing tetap menjadikan Alquran dan hadis sebagai pedoman dan rujukan utama dalam mengamalkan ajaran agama. Namun dalam menggali pemahaman dari kedua sumber tersebut memiliki perbedaan yang mendasar, terutama dalam paham imamah, kepemimpinan.

Dalam mażhab Syi'ah, Imāmah merupakan masalah yang sangat penting sehingga mengharuskan bagi mereka untuk menjadikannya sebagai rukun Islam yang keenam. Kaum Syi'ah menekankan peran Ali, menantu Nabi Muhammad Saw., setara dengan penekanan pada keesaan Allah dan kenabian Nabi Muhammad Saw. ${ }^{19}$ Begitupula sepeninggal Ali ra, kepemimpinan umat Islam beralih kepada anak-anaknya serta cucu-cucunya, dan ini seolah-olah merupakan ketetapan Allah. ${ }^{20}$

Versi lain mengatakan doktrin Syi'ah tentang imamah berdasarkan prinsip wasiat tentang serentetang pengganti dari satu nabi kenabi berikutnya, sebagai Nabi terahir Muhammad adalah pewaris dari Nabi-Nabi sebelumnya. Menurut doktrin ini Nabi itu mewariskan pengetahuannya kepada Ali sebagai wasiat pertama, menurut Syi'ah dia akan kembali kepada komponen berikutnya, ada hadis tentang penunjukkan Ali sebagai khalifah, pernyataan ini menunjukkak bahwa yang berhak menjadi khalifah adalah Ali. ${ }^{21}$

Dalam masalah Imāmah, Syi'ah Zaidiah, seseorang baru dapat diangkat sebagai imam apabila memenuhi lima kriteria, pengetahuan luas tentang agama, zahid (hidup hanya dengan beribadah), berjihad di jalan Allah Swt., dengan mengangkat senjata, dan berani. Di sebutkan bahwa sekte Zaidiah mengakui keabsahan khilafah atau imamah *Abu Bakar sa-Siddiq dan *Umar bin Khattab. ${ }^{22}$

Sama halnya dengan mażhab Syi'ah, mazhab Sunnipun meyakini pentingnya suatu kepemimpinan. Hanya saja dalam mazhab Sunni, kepemimpinan tidak diperoleh melalui warisan secara turun temurun tetapi haruslah melalui proses musyawarah dan mufākat. Hal inilah yang terlihat pada peristiwa di Saqifa Bani Sa'adah yaitu para sahabat memilih dan membaiat Abu Bakar sebagai khalifah. Demikian pula kaum Sunn̄̄ meyakini bahwa Rasulullah saw., meninggal tanpa menunjuk seorang pengganti. ${ }^{23}$ Hal ini berarti bahwa yang berhak menggantikan kepemimpinan Nabi saw tidak harus dari keluarga Rasulullah saw, akan tetapi siapa saja dari kaum Muslimin yang memenuhi

${ }^{19}$ John L. Esposito (ed), The Oxford Encyclopedia of the Modern Islamic World, Jilid. I (New York: Oxford University, 1995), h. 55.

${ }^{20}$ Taib Thahir. Ilmu Kalam. (Cet. VII; Jakarta: Widjaya.1986). h. 95.

${ }^{21}$ Mahmoud M. Ayoub, The Crisis of Muslim History Religion and Politics in Early Islam. (Oneworld Publications Sales and Editorial 185 Banbury Road Oxford OX2 7AR England, 2003). h. 19.

${ }^{22}$ Dewan Redaksi Ensiklopedi Islam. Insiklopedi Islam, (Jilid 5, Cet. IV; Jakarta: PT Ictiar Baru Van Hoeve. 2003). h. 7.

${ }^{23}$ Mircea Eliade, The Encyclopedia of Religion, vol. VII (New York: Simon dan Schulter Macmillan, 1995), h. 316. 
kualifikasi dan persyaratan berhak untuk dipilih melalui pemilihan secara demokratis.

Ahlus Sunnah, beritikad bahwasanya imam itu adalah manusia. Dia mengeahui dan tidak mengetahui. Dia bersifat benar dan bersifat salah, seperti manusia lain. Dia tidak mempunyai keitimewaan yang melebihkannya daripada manusia yang lain. Hanya dia telah dipilih (diangkat) oleh masyarakat untuk menjadi kepala negara lantaran ada kemampuannya, ada ilmunya dan baik akhlaknya, serta mempunyai kesanggupan untuk mendatangkan mamfaat bagi masyarakat. Semua manusia dari Adam. Adam dari tanah. Yang paling mulia hanyalah yang paling taqwa. ${ }^{24}$

Imam, menurut Ahlus Sunnah, tidak menerima wahyu dari Allah, tidak membawa syariat baru. Dia hanya mlaksanakan perintah Allah dan kadangkadang dia salah, tidak diharuskan manusia mengikutinya untuk mengikutinya jika dia salah dalam pemetintahannya.

Kepemimpinan dalam mażhab Sunn̄̄ diposisikan sebagai naib dari sahib al-syari'ah dalam memelihara dan menjaga agama. Pemimpin bertanggung jawab untuk membawa rakyatnya ke dalam ketaatan kepada Allah. Pemimpin adalah pemegang kekuasaan kehakiman, administrasi dan militer tetatapi bukan pemegang kekuasaan al-tasyri'iyah kecuali sebatas menafsirkannya atau berijtihad apabila tidak terdapat nash. ${ }^{25}$

Dari penjelasan diatas, dapat diketahui bahwa Mazhab Sunni berpendapat kepemimpinan tidak diperoleh secara turun temurun, tapi harus diperoleh dengan cara musyawarah dan mufakat. Pemimpin bertanggung jawab untuk membawa rakyatnya ke dalam ketaatan kepada Allah.

Ajaran Ahmadiyah mengakui kenabian dan kerasulan Nabi Muhammad Saw., juga diakui sebagai Khatam an-Nabiyyin, bahkan menurut ajaran ini, mengingkarinya berarti kafir. Tetapi Khatam an-Nabiyyin diartikan sebagai Nabi, sedangkan dalam keimanan Islam pada umumnya diartikan sebagai nabi terahir, tidak akan ada manusia yang menerima wahyu sesudah Nabi Muhammad Saw. ${ }^{26}$ Dengan demikian, menurut paham Ahmadiyah, hanya nabinabi yang membawa syariat saja yang sudah berakhir, sedangkan nabi-nabi yang tidak membawa syariat akan tetap berlangsung sampai sekarang.

Ahmadiyah memandang bahwa jenis nabi menurut paham mereka diberi wewenang oleh Tuhan atas dasar petunjuk-Nya, guna menghapus sebagian ajaran nabi sebelumnya yang dipandang tidak sesuai lagi saat itu, atau dengan menambah ajaran baru sehingga syariat itu menjadi lebih sempurna. Terjadinya perubahan sedikit-sedikit dari nabi-nabi yang datang kemudian, sehingga

\footnotetext{
${ }^{24}$ Teuku Muhammad Hasbi Ash Shiddieqi. Sejarah dan Pengantar Ilmu Tauhid / Kalam.(Cet. II; Semarang: PT. Pustaka Rizki Putra, 1999). h. 150.

${ }^{25}$ Lihat Ahmad Amīn, Fajr al-Islām, (Cet. XI; 1975. h. 271. Dalam hal ini, menurut hemat penulis, yang membedakan posisi kempimpinan sebagai pemegang kekuasaan, yaitu; kaum Syī’ah menganggap bahwa seorang pemimpin tetap memiliki kekuasaan al-tasyrì'iyah karena kepemimpinannya ditunjang oleh nash, sehingga posisi imām merupakan perpanjangan tangan dari hukumatullāh .

${ }^{26}$ Azyumardi Azra. Ensiklopedi Islam. (Cet. IV; Jakarta: PT Ichtiar Baru Van Hoeve. 2001). h. 90.
} 
syariatnya menjadi lebih sempurna daripada syariat-syariat yang dibawa nabinabi sebelumnya.

Ajaran Ahmadiyah ini mendapat tantangan dari ulama-ulama Sunni, di antaranya dari Abdul Haqqnal-Gaznawi, seorang maulwi dari Amritsar. Tantangan yang paling keras muncul dari Muhammad Husain, seorang tokoh pemimpin Ahlulhadis dari Batala (kota di distrik Gusdapur) dan editor koran berbahasa Urdu Isha'at-i Sunnah. Pada mulanya Muhmmad Husain merupakan pendukung kuat Ghulan Ahmad ketika pertama kali membaca Barahin-i Ahmadiyah dan al-Mahdi. ${ }^{27}$

Berdasar dari pemaparan di atas, jelas sekali ada perbedaan antara Ahmadiyah dan mazhab Islam lainnya terutama Sunn̄̄, demikian pula Syi' 'ah. Ahmadiyah sebagai gerakan mesianik yang mengklaim bahwa pendirinya adalah nabi dan bahwa pengganti nabi ini senantiasa mendapat ilham dari Tuhan, pada gilirannya Ahmadiyah bentrok dengan ulama yang merasa bahwa otoritas ulama sebagai penjaga ajaran Islam dan penafsir hukum Islam telah dirongrong. Perselisihan itu diperburuk oleh fakta bahwa ulama memfokuskan penentangan mereka pada Ahmadiyah menyangkut isu yang emosional, yakni kehormatan Muhammad saw, yang dikatakan telah dilecehkan oleh klaim Ghulām Ahmad bahwa dirinya adalah penerima wahyu setelah berakhirnya misi Muhammad saw.

Terlepas dari perbedaan paham yang dimiliki masing-masing mazhab, yang jelas bahwa ketiganya masih dipandang sebagai kelompok muslim (mereka beragama Islam), dan masing-masing eksis serta terus mengalami perkembangan dalam peta dunia Islam dewasa ini.

\section{Perkembangan Syi’ah, Sunnī, Ahmadiyah dalam Peta Dunia Islam}

Bersamaan dengan komunitas Sunni yang mengelaborasi konsep-konsep mereka mengenai Islam, komunitas Syi'ah, dan Ahmadiyah mengembangkan konsep Islam sesuai pahamnya, seiring dengan perkembangan zaman dan masa, serta situasi yang mereka hadapi. Dalam perspektif sejarahnya, bagi kaum Muslim Syi'ah isu terpenting bukanlah hukum atau mistisisme melainkan loyalitas terhadap khalifah Ali. Pada abad ketujuh dan kedelapan Masehi isu tersebut mengarah ke gerakan politis dalam bentuk perlawanan kepada Khilafah Umayyah dan Abbasiyah. Loyalitas kaum Muslim Syi'ah ini, berkali-kali berusaha merebut khilafah. ${ }^{28}$

Namun sejarah mencatat bahwa perjuangan mereka yang begitu lama dan berat untuk merebut kekhalifahan ternyata belum membuahkan hasil, dan justeru secara politis kaum Muslim Syi'ah ini mengalami penindasan dari Khilafah Umayyah dan Khilafah Abbasiyah. Namun demikian pada abad pertengahan peta dunia Islam hampir dikuasi Syi'ah terutama pada masa dinasti Fatimiyah. Dinasti Safawi telah memberikan kepada Iran semacam "negara

\footnotetext{
${ }^{27}$ Dewan Redaksi Ensiklopedi Islam. Ensiklopedi Islam, (Jilid I. Jakarta; PT Ictiar Baru Van Hoeve, 2003). h. 90.

${ }^{28}$ Ira M. Lapidus, A. History of Islamic Societies diterjemahkan oleh Ghufran A. Mas'adi dengan judul Sejarah Sosial Umat Islam Bagian Kesatu dan Dua (Cet. III; Jakarta: PT. RajaGrafindo Persada, 2003), h. 177
} 
nasional" dengan identitas baru, yaitu aliran Syi'ah yang menurut G.H. Jansen merupakan landasan bagi perkembangan Nasionalme Iran Modern. (15011722). ${ }^{29}$

Setelah terjadi revolusi konstitusional di Iran tahun 1906, maka para pemimpin agama dalam kalangan Syi'ah, yang kebanyakan mereka telah ikut serta dalam revolusi itu, mengundurkan diri dari dunia politik, setelah mereka menyadari bahwa gerakan sekularisasi telah mendapat kemenangan. Akibat dari itu, tahun-tahun berikutnya, yakni 1949 di kota Qum diadakan sebuah seminar tentang hubungan politik dengan agama, dan pada akahirnya muslim Syi'ah kembali menguasai Iran. Dalam pada itu, telah terjadi revolusi yang telah mengembalikan paham Syi'ah ke tengah-tengah percaturan dunia, baik dari segi keislaman maupun dari segi hubungan internasional.

Kelompok Syi'ah yang ada di Amerika adalah Isma'iliyah (Imam ke-7), yang meyakini bahwa pangeran Karim Aga Khan (1.1936) merupakan iman ke49. Kelompok ini telah membentuk komunitas makmur yang mencakup lebih dari 80 ribu orang pengikut di Kanada, khususnya di Vancouver dan Toronto sertakomunitas-komunitas kecil yang tersebar di seluruh Amerika Serikat, khususnya di New York dan California. Kelompok Isma'iliyah memberikan perhatian yang amat tinggi terhadap pendidikan. Mereka memiliki struktur organisasi yang yang kuat dan mampu mengembangkan lembaga-lembaga mereka secara efektif di Amerika Serikat. Terdapat pula kelompok-kelompok kecil semacam 'Alawiyah yang berasal dari Suriah, Lebanon, dan Turki serta Zaidiyah dari Yaman. ${ }^{30}$

Seperti yang telah disebutkan sebelumnya bahwa pasca-Revolusi Islam Iran, mazhab Syi'ah merebak keseluruh dunia, bukan saja di negara Barat seperti Amerika yang dijadikan sampel pada paragrap di atas, tetapi juga sampai ke Indonesia. Perkembangan mazhab Syi'ah di Indonesia di satu sisi merupakan khazanah dalam Islam. Akan tetapi, di sisi lain, akan timbul suatu "kejutan" baik dalam bidang ideologi, politik, dan budaya. Secara ideologi dan politik konsep imamiah yang dianut Syi'ah, mendapatkan berbagai reaksi dari kalangan Islam Sunni yang merupakan mayoritas di Indonesia. Reaksi ini bergerak sepanjang garis kontinum (along the cintinuum line) yang memiliki dua kutub ekstern (tho extreme poles). Penolakan total atas pandangan dan pemikiran Syi'ah sebagaimana tercermin dari sikap para ulama Sunni tampak sekali, apalagi dengan adanya keputusan MUI yang antara lain melarang pemberlakuan mazhab Syi'ah di negara ini.

Bagi Sunni, keadilan politik terletak pada mengakui penguasa sah melalui ijma' (konsensus komunitas). Bagi Syi'ah, keadilan itu terletak pada melanggengkan garis suksesi yang sah. Bagi sunni secara teoretis, legitimasi seorang penguasa dibatasi oleh kebutuhan akan syura' (musyawarah atau konsultasi) Namun demikian, kalangan ulama Sunni yang moderat tetap

\footnotetext{
${ }^{29}$ Ajid Thohir. Perkembangan Peradaban di Kawasan Dunia Islam Melacak AkarAkar Sejarah, Sosial, Politik, dan Budaya Ummat Islam.(Cet. II; Jakarta: Rajawali Pers. 2009). h. 166.

${ }^{30}$ John L. Esposito. Ensiklopedi Oxford Dunia Islam Modern, ( t. th ). h. 124.
} 
mengakui sisi ajaran Syi'ah kehususnya menyangkut figur dan peranan kepemimpinan ulama yang patut diteladani. Mereka mengakui bahwa Iran sangat beruntung memiliki figur kepemimpinan semacam Ayatullah Khomeini, yang mewarisi nilai spiritualitas tinggi utamanya dalam menentang kezaliman, tirani dan ketidakadilan.

Secara sederhana dapat dikemukakan bahwa dewasa terdapat dua kelompok utama dalam kalangan umat Islam, yaitu Sunnī dan Syī'ah yang dalam sejarahnya mengalami perkembangan yang signifikan dalam peta dunia Islam. Namun dengan memperhatikan sejarah tersebut, kelihatan bahwa populasi Sunnī lebih dominan ketimbangan Syī'ah dalam peta dunia Islam. Hal ini dipahami sejak meninggalnya Nabi saw., ternyata Abū Bakar, Umar, Utsman, dan Ali, menduduki posisi jabatan khalifah yang secara sah dalam paham Sunn̄̄ sudah menjadi doktrin keagamaan. Demikian pula, pada khalifahkhalifah seudahnya di masa Umayyah, Abbasiyah, sampai berkembangnya tiga kerajaan besar dalam sejarah, kaum Sunn̄̄ tetap menjadi dominan, perkembangannya di Indonesia, Mesir, Sudan, Malaisyah, Brunai Darussalam, Sudan, dan dominasi tersebut berlangsung sampai kini, dewasa ini. Karena itu, uraian tentang perkembangan Sunnī dalam bahasan ini, cukup sampai di sini.

Lain halnya dengan komunitas Ahmadiyah yang memang kelahirannya masih tergolong baru, dan terbelakang praktis bahwa perkembangannya belum begitu siginifikan dalam peta dunia Islam, dan perlu diteliti perkembangannya.

Pertumbuhan dan perkembangan Ahmadiyah dalam peta dunia Islam pada dasarnya dapat dibagi atas tiga fase, yaitu fase kebangkitan, fase ujian, dan perluasan daerah pengaruhnya, ${ }^{31}$ yang secara singkat diuraikan berikut :

Pertama, fase kebangkitan (1880-1990). Pada fase ini Mirza Ghulām Ahmadi mulai aktif menangkis serangan-serangan kaum propogandis dari berbagai pihak, terutama serangan kaum Hindu dan kaum Missionaris Kristen terhadap Islam. Di samping ia dan para pengikutnya aktif melakukan gerakan dakwah. Di saat yang sama, ia menyatakan dirinya sebagai mujaddid atau renovator abad ke-14, karena ia merasa telah ditunjuk oleh Tuhan untuk mempertahankan Islam. Ketika itu, Mirza Ghulām Ahmadi mengakui dirinya sebagai penjelmaan Isa al-Masih yang menerima wahyu secara berulang-ulang dan berkesinambungan. Karena demikian halnya, justru muslim Sunnī sebagai komonitas terbanyak sebagaimana yang telah dikemukakan, menentang keberadaan Mirza Ghulām Ahmadiyah tersebut, sehingga ia dituduh pembawa bid'ah dan karenanya ia dan pengikutnya dikucilkan dari komunitas muslim dan bahkan dipandang telah keluar dari Islam. Atas kenyataan ini, maka Ahmadiyah menghadapi gelombang permusuhan yang dasyhat terutama dari intern umat muslim sendiri. Sebagai konesekuensinya pendiri Ahmadiyah memikirkan nasib para pengikutnya yang dikenal dalam masyarakat sebagai golongan Mirzais atau Qadianis. Hasil pemikirannya itu menghasilkan kesimpulan bahwa

\footnotetext{
${ }^{31}$ Muslih, Fathoni. Faham Mahdi Syi'ah dan Ahmadiyah dalam Perspektif. (Cet. I; Jakarta: RajaGrafindo Persada, 1994). h. 59-69.
} 
pahamnya harus didakwakan secara sembunyi-sembunyi pada tahap atau pada fase awal kebangkitannya

Kedua, fase ujian (1900-1908) bagi jemaat Ahmadiyah. Pada fase ini, Ahmadiyah telah berani mengembangkan pahamnya secara terang-terangan, dan secara berani mendakwahkan bahawa Mirza Ghulām Ahmadiyah sebagai "nabi" dan menghormatinya seperti layaknya seorang rasul Tuhan. Dalam perkembangan dakwahnya, ia pun mengaku tidak hanya sebagai nabi tetapi juga al-Masih. Sebagai akibatnya, maka tantangan sengit bukan saja datang intern Islam tetapi juga dari pihak Kristen. Ini adalah sebuah ujian berat bagi Ahmadiyah, apakah pahamnya mampu bertahan dengan tantangan tersebut, sampailah pada saat ketika pendirinya meninggal akibat tekanan dari berbagai pihak keutuhan dan kesatuan Ahmadiyah terpecah. Sebab perpecahan itu adalah pada masalah khalifah (pengganti pimpinan). Pada gilirannya, tampillah Maulawi Nuruddin menggantikan Mirza Ghulām Ahmadiyah, namun ia tidak diakui oleh semua pengikut Ahmadiyah, kecuali hanya sedikit saja di antara mereka. Pada akhirnya, tampil lagi pemimpin baru yakni Maulana Muhammad Ali setelah wafatnya Maulawi Nuruddin. Dengan kepemimpinan Maulana Muhammad Ali tampak pengikut Ahmadiyah lebih agresif lagi dan terus mengalami perkembangan.

Ketiga, fase perluasan daerah dan pengaruhya (1908-sampai sekarang), di mana dalam masa ini terutama pada tahun 1914 terpecahlah Ahmadiyah menjadi dua sekte, yakni Ahmadiyah Qadiani, dan sekte Ahmadiyah Lahore. Sekte pertama berkeyakinan bahwa kenabian tetap terbuka sesudah Muhammad saw, tetapi mereka menganggap bahwa pemimpin Ahmadiyah tiada lain adalah mujaddid saja, tidak sama persis dengan kedudukan Muhammad saw. Yang kedua, berkeyakinan bahwa Maulawi Muhammad Ali adalah nabi dan rasul yang berpusat di Lahore. Walaupun Ahmadiyah terpecah menjadi dua sekte dan sulit untuk bersatu, namun kedua sekte ini sangat aktif dan intensif dalam usaha mewujudkan cita-cita kemahdiannya, terutama di kalangan masyarakat Kristen Barat.

Pengikut masing-masing sekte mendirikan mesjid-mesjid sebagai pusat kegiatan, menterjemahkan Alquran berikut komentar-komentarnya ke dalam bahasa Asing. Di samping itu Ahmadiyah tampaknya juga aktif mendirikan berbagai lembaga pendidikan serta pusat-pusat kesehatan di berbagai tempat di kawasan Asia dan Afrika, perkembangannya sampai ke Persia, India Pakistan. Sebagaimana diketahui, Ahmadiyah masuk ke Indonesia pada tahun 1924 dibawa oleh dua orang muballig yaitu Maulana Ahmad dan Mirza Wali Ahmad. Mereka memulai kegiatannya di Yogyakarta. Setahun kemudian yaitu tahun 1925 sekte Qadian menyusul dibawa oleh seorang muballignya bernama Rahmad 'Ali H.A.O.T, dan mulai mendakwahkan ajarannya di Padang. Kedua sekte tersebut berlomba menanamkan pengaruhnya, dan rupanya mendapat tanggapan positif dari masyarakat dan mendapat kesuksesan dalam misinya.

\section{PENUTUP}

A. Kesimpulan 
Berdasar pada permasalahan yang dikaji, dan kaitannnya dengan uraianuraian yang telah dikemukakan sebelumnya, maka dapat dirumuskan kesimpulan sebegai berikut :

1. Mażhab Syī'ah yang dikenal mażhab Ahlul Bait telah ada benihnya sejak Nabi saw masih hidup. Mażhab ini lahir karena didukung oleh beberapa nash dan adanya masalah politik terutama di akhir masa kekhalifahan. Selanjutnya mażhab Sunnī lahir karena adanya masalah teologi. Mażhab ini lazimnya dikenal mazhab Ahlus Sunnah yang merujuk pada aliran Asy'ariyah dan Maturidiyah. Seiring dengan perkembangan zaman maka muncul lagi mażhab baru yang disebut Ahmadiyah dipelopori Mirza Ghulam Ahmad. Mażhab ini merupakan gerakan mesianik dalam Islam modern yang kontroversial.

2. Mażhab Syī'ah, Sunn̄̄, dan Ahmadiyah masing-masing memiliki paham tentang kepemimpinan. Menurut Syī'ah setelah wafatnya Nabi saw, maka Ali yang paling berhak menggantikannya sebagai pemimpin spiritual, demikian seterusnya jabatan kepemimpinan berlanjut pada keturunan Nabi saw. Sementara menurut Sunn̄̄, kepemimpinan tersebut diserahkan kepada siapa yang dipilih oleh umat seperti terpilihnya Abu Bakar menggantikan Nabi saw, seterusnya kepada Umar, Utsman, dan Ali, mereka adalah khulafa' al-rasyidin. Selanjutnya menurut Ahmadiyah sepeninggal Nabi saw, missinya tetap berlanjut dengan munculnya nabi-nabi baru dan mereka mendapatkan ilham atau semacam wahyu dari Tuhan untuk mengembangkan agama.

3. Peta dunia Islam menunjukkan bahwa mażhab Syīah, Sunnī, dan Ahmadiyah mengalami perkembangan yang signifikan. Perkembangan Syī'ah terutama setelah revolusi Iran, demikian pula Sunn̄̄ jauh sebelumnya telah berkembang. Sedangkan Ahmadiyah yang karena kelahirannya belakangan maka perkembangannya tidak begitu signifikan ketimbang dengan dua mażhab yang telah disebutkan. Berkenaan dengan itulah bisa dipastikan bahwa komunitas Islam terbanyak dewasa ini adalah yang berpaham Sunn̄̄, disusul Syī'ah, dan kemudian Ahmadiyah.

\section{B. Implikasi}

Penulis melihat bahwa asal usul lahirnya Syī'ah, Sunnī, dan Ahmadiyah memiliki latar belakang yang berbeda, dalam perkembangan kepemimpinannya masing-masing berbeda dan memiliki paham perbedaan yang mendasar terutama pada persoalan kepemimpinan, memiliki per-kembangan yang unik di mana masing-masing sangat menarik untuk dikaji dan diteliti lebih lanjut. Berkenaan dengan itu, tentu saja hasil pembahasan dalam makalah ini belum final, sehingga disarankan agar diskusi dan telaahan lebih mendalam lagi sangat diharapkan.

Dengan demikian, disarankan agar Peta dunia Islam: Syi'ah, Sunni, dan Ahmadiyah tetap menjadi kajian dan menjadi bahan diskusi untuk menemukan hal-hal baru yang belum terangkum dalam makalah ini. 


\section{DAFTAR PUSTAKA}

Al-Qur'an al-Karim

Ash Shiddieqi, Teuku Muhammad Hasbi. Sejarah dan Pengantar Ilmu Tauhid / Kalam. Cet. II; Semarang: PT. Pustaka Rizki Putra, 1999.

Abū Zahrah, Muhammad. Tarīkh al-Mazāhib al-Islamiyah. Mesir: Dār al-Fikr, 1979.

Aceh, Abu Bakar. Syi'ah Rationalisme dalam Islam. Solo: Ramadlani, 1984.

Ali, Maulana Muhammad. Mirza Ghulan Ahmad of Qadian, His Life and Mission Lahore: Ahmadiyah Anjuman Ish'at Islam, 1979.

Al-Suyuthy , Al-Iman al-Hafid Jalaluddin Abd Al-Rahman bin Abu Bakar. Tarikh al-Khulafa. Cet. I; Mesir: Matbaah as-Saadah, 1952.

Al-Usairy, Ahmad. Sejarah Islam Sejak Zaman Nabi Adam Hingga Abad XX. Di terjemahkan oleh Samson Rahman. Cet. VIII; Jakarta: Akbar Media,2010.

Amīn, Ahmad. Fajr al-Islām, Cet. XI; 1975.

Ayoub, M. Mahmud, The Crisis of Muslim History Religion and Politics in Early Islam. Oneworld Publications Sales and Editorial 185 Banbury Road Oxford OX2 7AR England, 2003.

Azyumardi Azra. Ensiklopedi Islam. Cet. IV; Jakarta: PT Ichtiar Baru Van Hoeve. 2001

D.Litt, Margoliouth, D.S. Umayyah and 'Abbasids Being The Fourth Part of Jurji Zaydan's of Islamic Civilization. London: Kitab Bhavan New Delhi, 1978

Dewan Pimpinan Majelis Ulama Indonesia, Penetapan Fatwa MUI dalam "Departeman Agama RI". Jakarta: Direktorat Jenderal Bimbingan Masyarakat Islam dan Penyelanggaraan Haji, 2003.

Dewan Redaksi Ensiklopedi Islam. Ensiklopedi Islam, Jilid I. Jakarta; PT Ictiar Baru Van Hoeve, 2003.

------.Ensiklopedi Islam, Jilid V. Jakarta; PT Ictiar Baru Van Hoeve, 2003.

Eliade, Mircea. The Encyclopedia of Religion, vol. VII. New York: Simon dan Schulter Macmillan, 1995.

Esposito, John L (ed), The Oxford Encyclopedia of the Modern Islamic World, Jilid. I Cet. II; New York: Oxford University, 1995.

--------. The Oxford Encyclopedia Of The Modern Islamic World. New York: Oxfoord Universitt 1995

-------. Ensiklopedi Oxford Dunia Islam Modern, ( t. th ).

Fathoni, Muslih. Faham Mahdi Syi'ah dan Ahmadiyah dalam Perspektif. Cet. I; Jakarta: RajaGrafindo Persada, 1994.

Glasse, Cyril. The Concise Encyclopedia of Islam diterjemahkan oleh Ghufran Mas'adi dengan judul Ensiklopedi Islam; Ringkas. Cet. III; Jakarta: RajaGrafindo Persada, 2002.

George, Jordac. Suara Keadilan Sosok Agung Ali bin Abi Thalib R.A. Cet. II; Jakarta: Lentera, 2000.

Haekal, Muhammad Husain. Sejarah Hidup Muhammad. Cet.36.Jakarta: PT. Pustaka Litera AntarNusa, 2008

Lambton, Ann K.S. State and Govermen in Medival Islam. Oxford: University Press, 1981. 
Lapidus, Ira M. A. History of Islamic Societies diterjemahkan oleh Ghufran A. Mas'adi dengan judul Sejarah Sosial Umat Islam Bagian Kesatu dan Dua. Cet. III; Jakarta: PT. RajaGrafindo Persada, 2003.

Mahmūd, Abd al-Halim. al-Tafkīr al-Falsafì fì al-Islām. Cet. II; Kairo: Dār alMa'ārif, t.th.

Nasution, Harun. Teologi Islam; Aliran-aliran Sejarah Analisa Perbandingan. Cet. V; Jakarta: UI-Press, 1986.

Nasir, Sahilun A. Pemikiran Kalam (Teologi Islam) Sejarah, Ajaran dan Perkembangannya. Cet. I; Jakarta: PT RajaGrafindo Persada, 2010

Rosihon Anwar, Abdul Rozak. Ilmu Kalam. Cet. II; Bandung: CV. Pustaka Setia. 2006

Shihab, M. Quraish Sunnah-Syiah, Bergandengan Tangan! Mungkinkah? Kajian Atas Konsep Ajaran dan Pemikiran, Cet.I; Jakarta: Lentera Hati, 2007.

Syadzali, H. Munawir. Islam dan Tata Negara; Jaran, sejarah dan Pemikiran, Edisi V. Jakarta: UI Press, 1993.

Taufik, Abdullah. Ensiklopedia Tematis Dunia Islam. Jilid 3. Jakarta: PT Ichtiar Baru Van Hoeve, 2002.

Thahir, Taib. Ilmu Kalam. Cet. VII; Jakarta: Widjaya.1986.

Thohir, Ajid. Perkembangan Peradaban di Kawasan Dunia Islam Melacak Akar-Akar Sejarah, Sosial, Politik, dan Budaya Ummat Islam. Cet. II; Jakarta: Rajawali Pers. 2009.

Yatim, Badri. Sejarah Peradaban Islam Dirasah Islamiyah II. Cet. XXI; Jakarta: Rajawali Pers. 2008. 